\title{
Distribution and Movements of Brood-Rearing Lesser Snow Geese in Relation to Petroleum Development in Arctic Alaska
}

\author{
STEPHEN R. JOHNSON ${ }^{1}$
}

(Received 10 August 1997; accepted in revised form 22 March 1998)

\begin{abstract}
Environmental scientists were concerned that construction of the Endicott Project in the outer Sagavanirktok River delta, east of Prudhoe Bay, Alaska, would obstruct brood-rearing movements of Alaska's largest established nesting population of lesser snow geese (Chen caerulescens caerulescens). During 1980-84, prior to the Endicott Project, the distribution of snow goose flocks during the brood-rearing period was generally less than $5 \mathrm{~km}$ from the coast and $15 \mathrm{~km}$ from the nesting colony. Prior to development, the average distance between brood-rearing areas used during consecutive years by individual banded birds was $4.7 \pm 2.9 \mathrm{~km}$ (mean \pm s.d.). After development commenced during winter 1984-85, the distribution of brood-rearing flocks expanded inland as far as $9 \mathrm{~km}$ and eastward as far as $32 \mathrm{~km}$ from the nesting colony. The average distance between brood-rearing areas used during consecutive years by individual banded birds was $8.0 \pm 7.5 \mathrm{~km}$. The proportion of brood-rearing snow geese captured on the east side of the Endicott Road and Causeway (east of the nesting colony) during the post-construction years (198593) was not significantly different from the proportion using the same area before construction (1980-84). The hypothesis that the Endicott Road and Causeway obstructed eastward movements of brood-rearing snow geese can be rejected.
\end{abstract}

Key words: Western Arctic, Alaska, lesser snow goose, brood-rearing, oil development

RÉSUMÉ. Les spécialistes de l'environnement s'inquiétaient que la construction du pont-jetée Endicott dans le delta externe du Sagavanirktok situé à l'est de Prudhoe Bay en Alaska puisse gêner les déplacements reliés à l'élevage des oisons de la plus importante population nicheuse de la petite oie des neiges (Chen caerulescens caerulescens) en Alaska. Durant la période allant de 1980 à 1984, soit avant le projet Endicott, la distribution des volées d'oies des neiges durant la période d'élevage de la couvée s'étendait en général à moins de $5 \mathrm{~km}$ de la côte et $15 \mathrm{~km}$ de la colonie nicheuse. Avant la mise en valeur, la distance moyenne entre les zones d'élevage des oisons utilisées durant des années consécutives par des individus bagués était de 4,7 $\pm 2,9 \mathrm{~km}$ (moyenne \pm écart-type). Durant l'hiver de 1984-85, après le début de la mise en valeur, la distribution des volées en train d'élever des oisons s'est élargie à l'intérieur des terres jusqu'à $9 \mathrm{~km}$ et, vers l'est, jusqu'à $32 \mathrm{~km}$ de la colonie nicheuse. La distance moyenne entre les zones d'élevage des oisons utilisées durant des années consécutives par des individus bagués était de 8,0 \pm 7,5 km. La proportion d'oies des neiges en train d'élever des oisons capturées à l'est de la route et du pont-jetée Endicott (situés à l'est de la colonie nicheuse) durant les années suivant la construction (1985-93) n'était pas sensiblement différente de la proportion qui utilisait la même région avant la construction (1980-84). On rejette l'hypothèse que la route et le pont-jetée Endicott ont gêné les déplacements vers l'est de l'oie des neiges en période d'élevage.

Mots clés: Arctique occidental, Alaska, petite oie des neiges, soins à la couvée, exploitation pétrolière

Traduit pour la revue Arctic par Nésida Loyer.

\section{INTRODUCTION}

The lesser snow goose colony on Howe Island near Prudhoe Bay, Alaska (Fig. 1), is the only established snow goose colony in the United States (Johnson, 1995, 1996; Johnson et al., 1995), and it is the only known location where snow geese nest and rear broods in an active oil field environment (Johnson and Troy, 1987; Johnson and Herter, 1989; Johnson, 1994). The Howe Island population increased tenfold during the 14-year period of this study (Table 1).

After hatching, adult snow geese from Howe Island aggregate into small flocks and move their goslings to salt marsh habitats, with graminoid vegetation (Puccinellia phryganodes, Carex subspathacea, C. aquatilus var. stans) preferred during the brood-rearing period (Johnson, 1987). Along the Beaufort Sea coast, these salt marshes typically occur in or adjacent to low-lying river deltas subject to periodic inundation during storm surges. Another feature of most brood-rearing habitats is the close proximity of large waterbodies that serve as escape habitat for the flightless adults and their goslings, both of which are easy prey for arctic foxes (Alopex lagopus), grizzly bears (Ursus arctos), and other predators (Truett et al., 1997). Broodrearing habitats are critical to Arctic-nesting geese because of the limited time available for feeding, growth, and development of flight before the onset of cold weather and fall migration (Giroux et al., 1984; Sedinger and Raveling, 1984; Johnson and Herter, 1990; Hughes et al., 1994).

${ }^{1}$ LGL Limited, environmental research associates, 9768 Second Street, Sidney, British Columbia V8L 3Y8, Canada; srj@islandnet.com

(C) The Arctic Institute of North America 


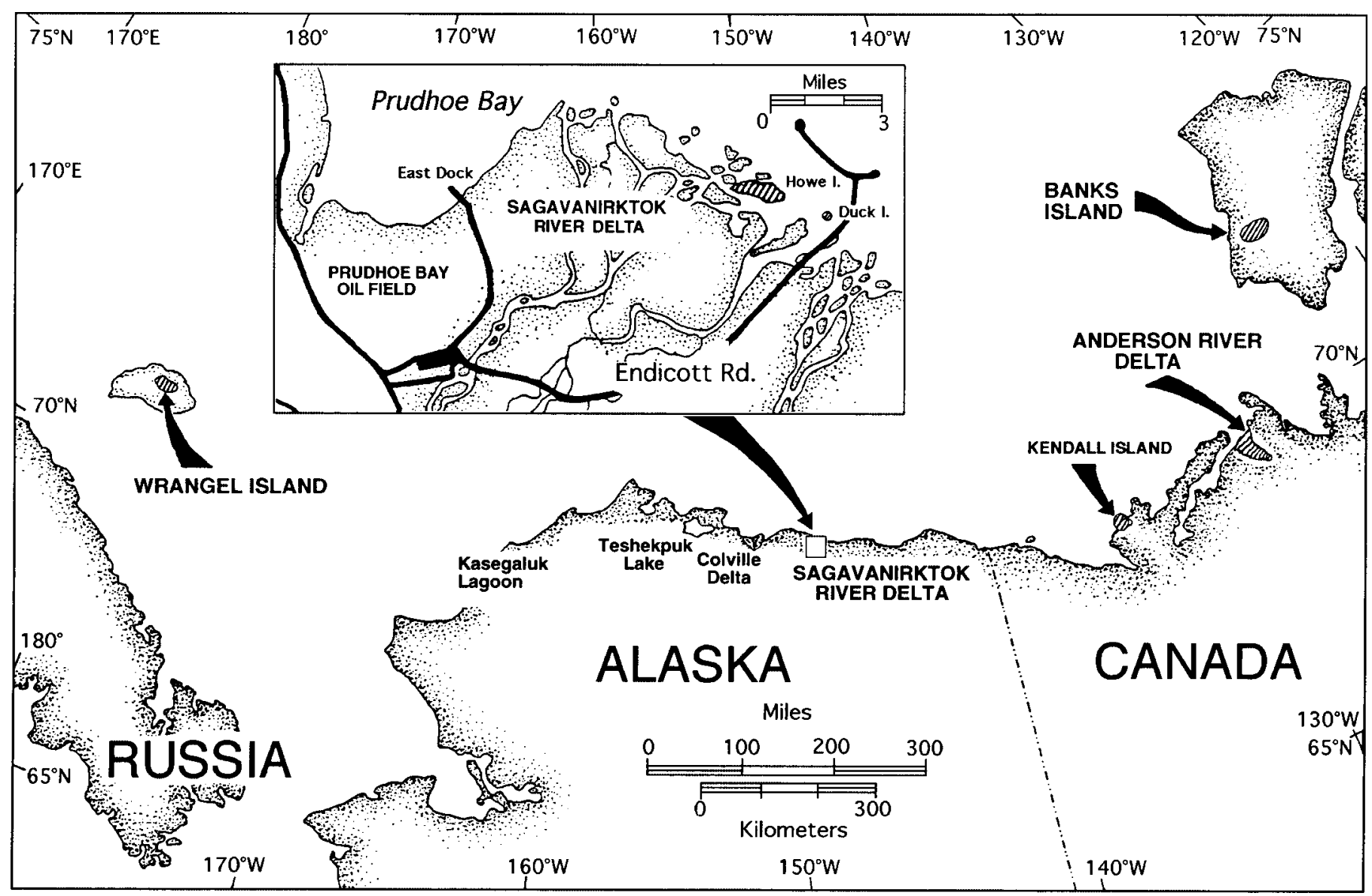

FIG. 1. The Howe Island, Alaska, snow goose colony relative to other snow goose colonies in the Western Arctic.

Snow geese often use the same brood-rearing areas, usually near the nesting colony, year after year (Cooke and Abraham, 1980; Healey et al., 1980; Kerbes et al., 1990; Reed and Plante, 1994).

The Sagavanirktok River delta and adjacent salt marshes are used as brood-rearing habitats by the Howe Island snow goose population. During the winter of $1984-85$, the Endicott Project commenced with construction of the Endicott Road, which bisected the Sagavanirktok River delta (Fig. 1). The road extended as a causeway several kilometers offshore to two artificial drilling islands. The causeway passed seaward about $2 \mathrm{~km}$ east of the snow goose nesting colony on Howe Island (Fig. 1). Construction of the road and causeway was completed by late fall 1985, but some modifications (dock, breach, and pipeline construction) occurred during 1986-87 and 1993. Drilling and production have taken place on the artificial islands since 1988, but activities within the study area in the Sagavanirktok River delta have been limited to travel along the access road and causeway, oil spill containment and cleanup exercises, and various biophysical scientific investigations.

Environmental scientists hypothesized that activities related to petroleum developments in the Sagavanirktok River delta, especially road and causeway construction and use, might pose a significant obstacle to brood-rearing flocks of flightless snow geese as they dispersed (walked) eastward from Howe Island toward brood-rearing areas. This hypothesis was tested by analyzing data collected during annual capture and banding programs of broodrearing snow geese in the Sagavanirktok River delta area.

\section{METHODS}

The number and distribution of brood-rearing snow geese were determined by aerial surveys and by banding programs that resulted in the capture and banding of all productive adults and their goslings for 14 years, 5 years before petroleum development and 9 years after development commenced. Some failed and nonbreeding adult and subadult geese departed the study area before banding each year, but over the course of the study most birds in the population were eventually captured and banded, and many were recaptured annually (Johnson, 1995).

Daily observations from ground-based observation stations and during the frequent aerial surveys in the Endicott Development Project Snow Goose Monitoring Program (Burgess et al., 1991:Chap. 4:13) indicated that "By about 2 weeks after peak hatching, group sizes and composition had stabilized, the locus of activity of each group had become established, and dispersal ceased." By mid- to late 
TABLE 1. Numbers of snow geese captured during banding programs in the Sagavanirktok River delta, Alaska, 1980-93.

\begin{tabular}{crrrr}
\hline \hline Year & Goslings & Yearlings & Adults & Total \\
\hline 1980 & 84 & 3 & 78 & 165 \\
1981 & 234 & 15 & 162 & 411 \\
1982 & 44 & 5 & 153 & 202 \\
1983 & 297 & 13 & 274 & 584 \\
1984 & 222 & 10 & 187 & 419 \\
1985 & 271 & 8 & 313 & 592 \\
1986 & 323 & 1 & 316 & 640 \\
1987 & 81 & 15 & 317 & 413 \\
1988 & 480 & 9 & 447 & 936 \\
1989 & 184 & 7 & 201 & 392 \\
1990 & 909 & 28 & 682 & 1619 \\
1991 & 6 & 7 & 22 & 35 \\
1993 & 838 & 1 & 826 & 1665 \\
All Years & 3973 & 122 & 3978 & 8073 \\
\hline \hline
\end{tabular}

July, brood-rearing flocks had reached their maximum sizes, and the flocks remained in the same general areas (generally within $1-3 \mathrm{~km}$ ) until they departed the study area in mid- to late August.

Thus, post-hatching snow geese moved over great distances, and groups often intermingled until they settled into discrete flocks in brood-rearing habitats several weeks after the peak of hatching. Aside from some adult geese wearing neck collars, it was not possible to identify individual geese in brood-rearing flocks without capturing and examining them. Since the geese were captured and examined only once each year, all analyses are based on comparing the locations where individual geese in broodrearing flocks were captured and banded in one year with their recapture locations in subsequent years.

All adults and goslings were captured and banded annually in late July or early August, two to three weeks after the peak in hatching, after brood-rearing flocks had stabilized, when goslings were about half grown, and before adults had regained flight. All captured geese were banded with aluminum leg-bands, and many adults were also fitted with blue-and-white plastic neck-bands. Details of the capture and banding procedures are described in Johnson et al. (1995). In summary, the annual capture and banding programs occurred over a $2-3$ day period. The locations of all brood-rearing flocks were marked on a map during an aerial survey of the study area conducted prior to banding. Brood-rearing flocks consisted of family groups as well as some failed breeders or nonbreeding birds. All people and equipment were moved by helicopter, and the researchers worked across the study area from east to west to prevent recently released flocks from mixing with those yet to be captured.

Starting in 1980, the first year of the study, capture locations for each brood-rearing flock were assigned consecutive numbers. A database was constructed that identified each captured bird by its leg-band number, brood-rearing flock number, capture co-ordinates, capture/ banding date, age, sex, and other information relevant to

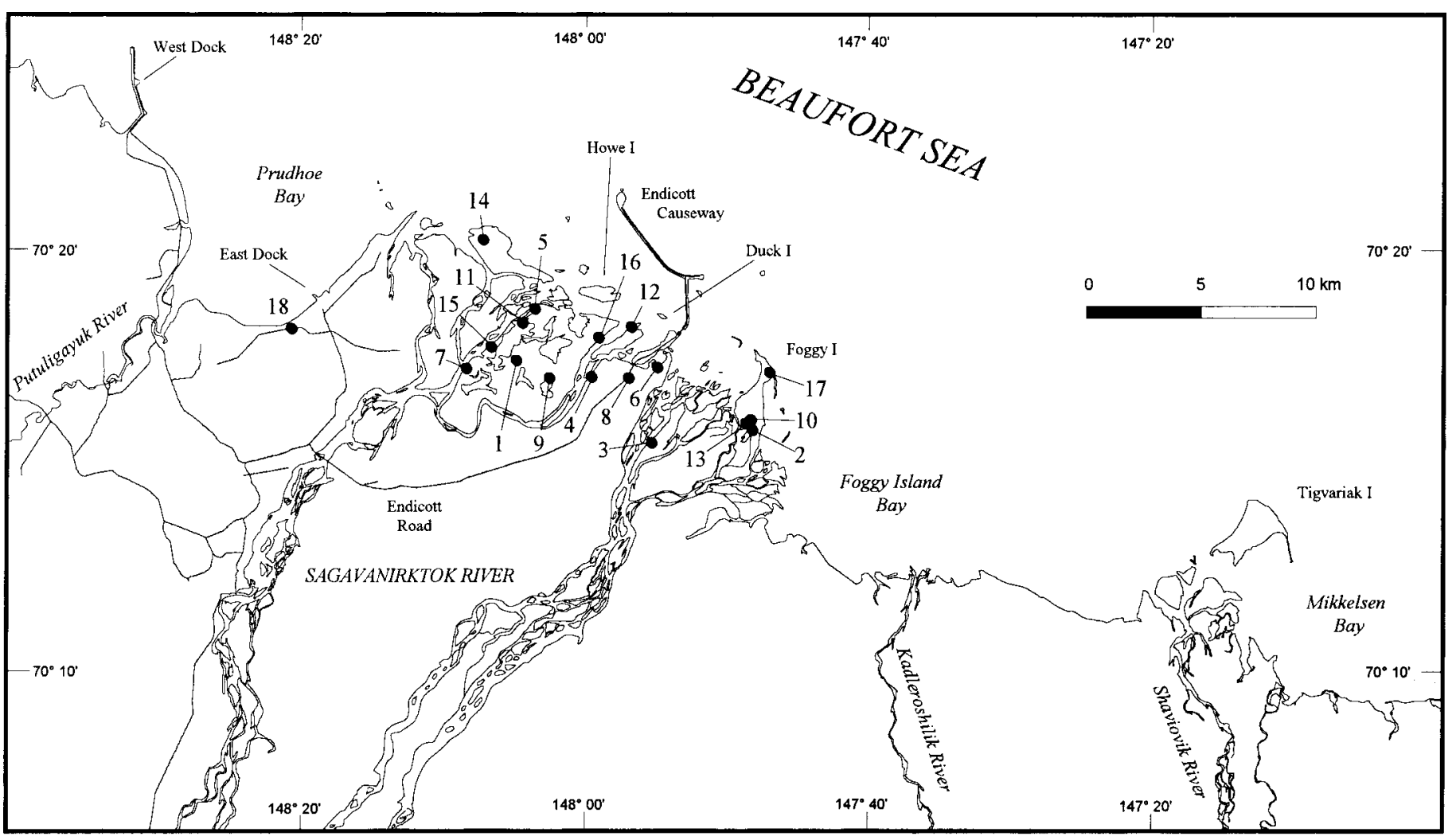

FIG. 2. Locations where brood-rearing flocks of snow geese were captured in 1980-84 before commencement of the Endicott Development Project, Alaska. Each flock location is numbered sequentially, and the numbers correspond to flock numbers given in Appendix 1. 


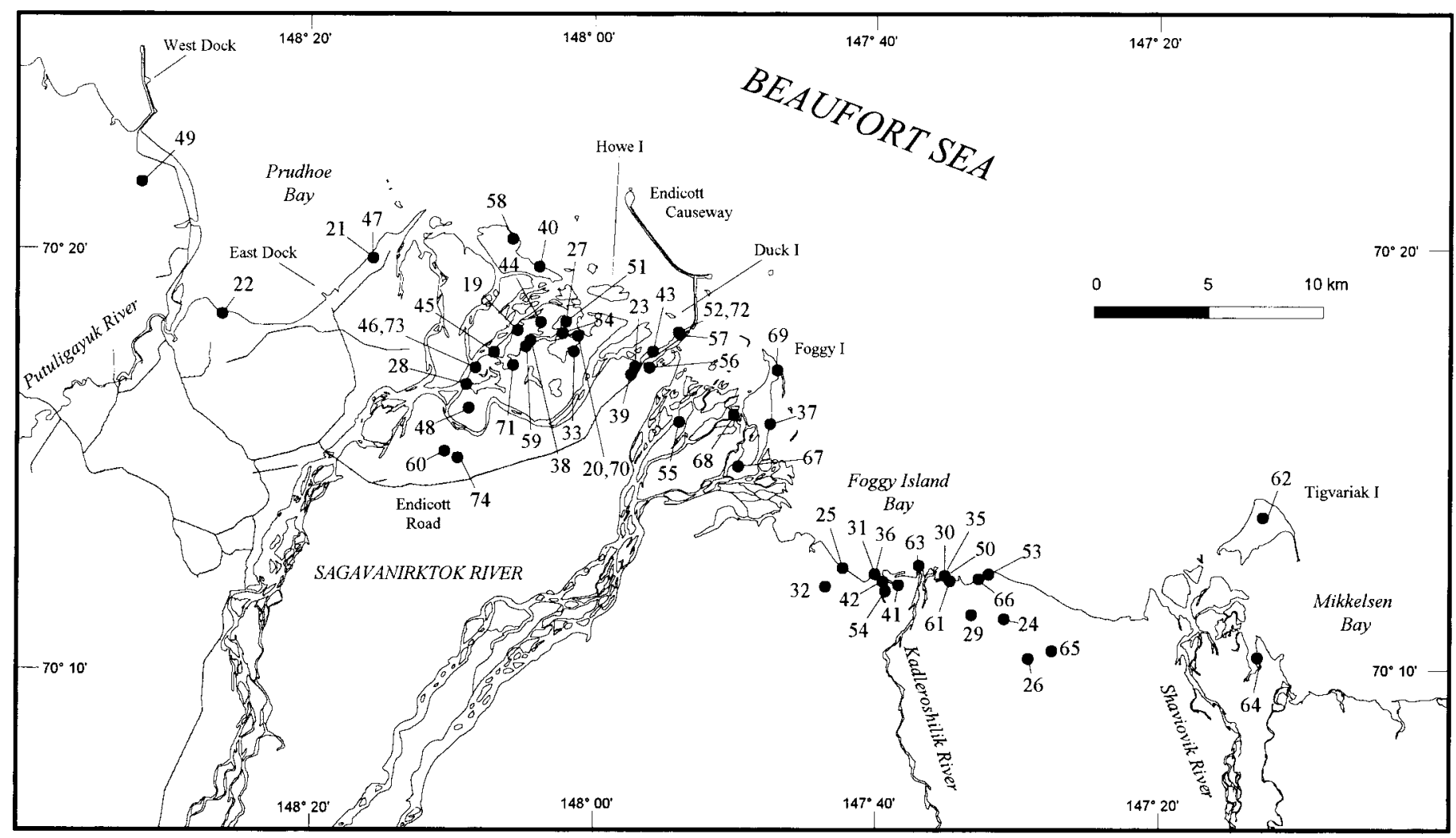

FIG. 3. Locations where brood-rearing flocks of snow geese were captured after commencement of the Endicott Development Project, Alaska, from 1985 to 1993. Each flock location is numbered sequentially, and the numbers correspond to flock numbers given in Appendix 1.

the study. Flock numbers shown in Figures 2 and 3 correspond to Flock numbers given in Appendix 1. Thus, it was possible to determine whether individual geese moved between brood-rearing areas in consecutive years by tracking their band numbers relative to brood-rearing flock numbers. For example, geese originally captured in Flock 1 in 1980 were recaptured in Flocks 3 through 10 in 1981, 1982, and 1983, and geese originally captured in Flock 2 in 1980 were recaptured in Flocks 3, 4, and 6 in 1981, in Flock 8 in 1982, in Flocks 10 and 12 in 1983, and in Flock 13 in 1984 (Figs. 2 and 3, Appendix 1). Since members of pairs, family groups, and siblings were not distinguishable in brood-rearing flocks, all marked birds were pooled in our analyses and we did not categorize our data by age, sex, or family status.

Data were analyzed using Arc/Info GIS software to construct maps and measure the distances moved by geese from one brood-rearing area (flock) to another in subsequent years. Because of weather- and predation-related breeding failures in 1991 and 1992, few or no birds were banded; therefore, data for those years were not used in statistical analyses.

\section{RESULTS}

Before petroleum development (1980-84), brood-rearing flocks of snow geese in late July were restricted to the outer portion of the Sagavanirktok River delta-up to $5 \mathrm{~km}$ from the coast and up to $15 \mathrm{~km}$ from the nesting colony. The geese were distributed from East Dock in the west to Foggy Island on the far eastern side of the delta (Fig. 2). Before petroleum development, the mean distance moved by geese from one year to the next was $4.8 \pm 2.9 \mathrm{~km}$, with $40.2 \%$ of birds using areas within $3 \mathrm{~km}$ of areas used the previous year, and $90.8 \%$ using areas $8 \mathrm{~km}$ or less from areas used the previous year (Fig. 4). Before development, the unimodal peak of distance moved from one year to the next was $3 \mathrm{~km}$ (Fig. 4).

After petroleum development (1985-93), many geese continued to use the same general area in the Sagavanirktok River delta for brood-rearing, and a large proportion of geese continued to use the same specific brood-rearing location from one year to the next. However, starting in 1985, several flocks moved $25 \mathrm{~km}$ southeast of Howe Island to rear their broods in the Kadleroshilik River delta (Fig. 3); at least one flock was captured in this location, or farther east, in every year since 1985. In 1990, some snow geese moved $32 \mathrm{~km}$ east of Howe Island to rear their broods in the Shaviovik River delta (Fig. 3), and other flocks ranged as far as $9 \mathrm{~km}$ inland from the coast to rear their broods along the Endicott Road (Fig. 3).

Flocks found using areas east of the Sagavanirktok Delta in 1985 comprised predominately (46 of 62 geese, $74.2 \%$ ) geese from flocks (flock nos. 10, 13, and 17; Appendix 1) that reared broods in 1983 and 1984 on Foggy 


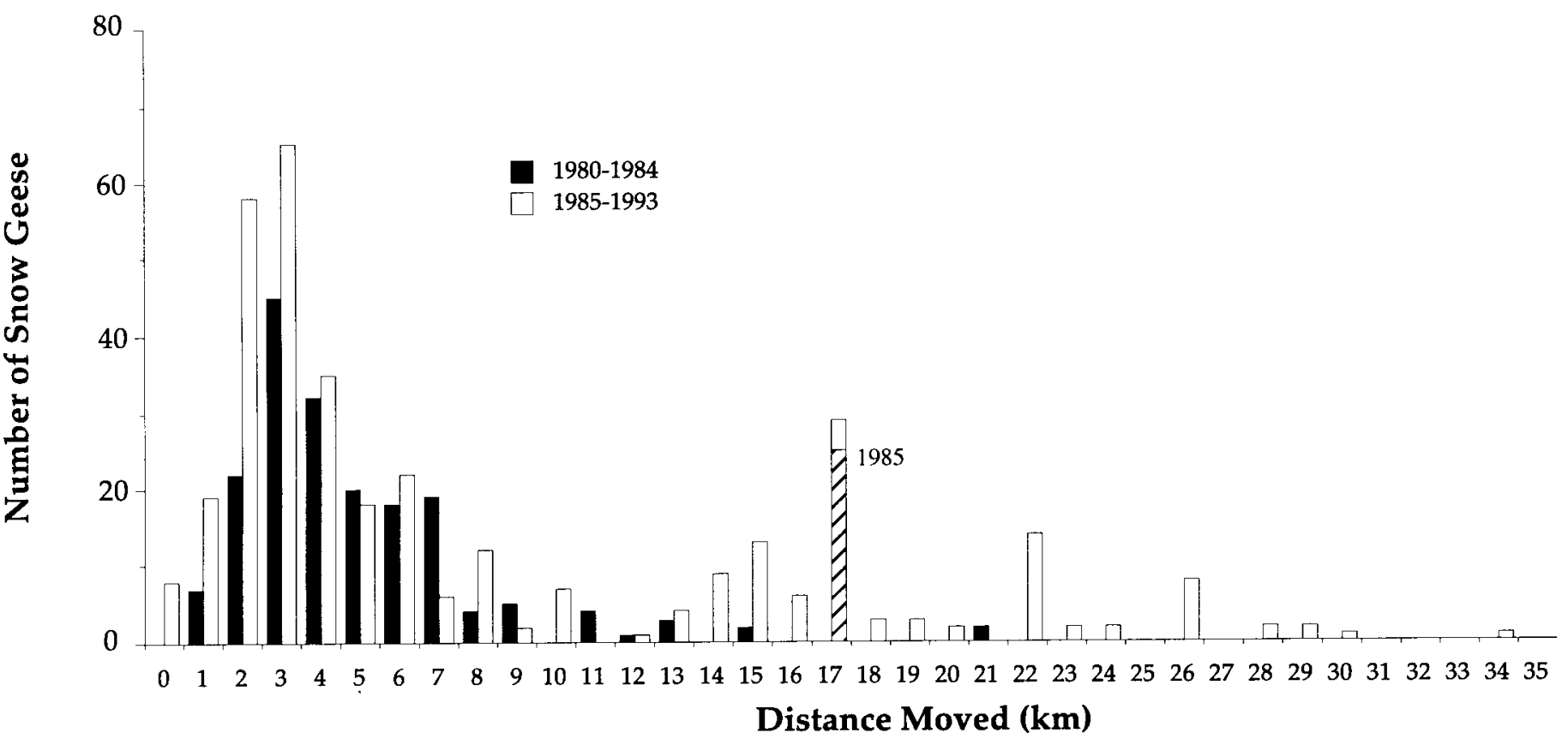

FIG. 4. Distances moved by banded birds between brood-rearing areas in consecutive years before (1980-84) and after (1985-93) commencement of the Endicott

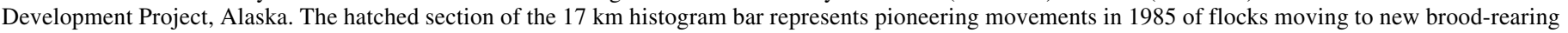
areas in the Kadleroshilik River delta (Fig. 3).

TABLE 2. The numbers and proportions of snow goose individuals and flocks captured west and east of the Endicott Road/Causeway in the Sagavanirktok River delta, Alaska, before and after road/causeway construction commenced in 1984-85.

\begin{tabular}{|c|c|c|c|c|c|c|c|c|c|}
\hline & & \multicolumn{4}{|c|}{ West Side } & \multicolumn{4}{|c|}{ East Side } \\
\hline & & No. of Flocks & $\%$ & No. of Birds & $\%$ & No. of Flocks & $\%$ & No. of Birds & $\%$ \\
\hline \multirow[t]{6}{*}{ Before } & 1980 & 1 & 50.0 & 101 & 61.2 & 1 & 50.0 & 64 & 38.8 \\
\hline & 1981 & 2 & 50.0 & 166 & 40.4 & 2 & 50.0 & 245 & 59.6 \\
\hline & 1982 & 1 & 50.0 & 43 & 21.3 & 1 & 50.0 & 159 & 78.7 \\
\hline & 1983 & 3 & 75.0 & 375 & 64.2 & 1 & 25.0 & 209 & 35.8 \\
\hline & 1984 & 4 & 66.7 & 246 & 58.7 & 2 & 33.3 & 173 & 41.3 \\
\hline & $1980-84$ & 11 & 61.1 & 931 & 52.3 & 7 & 38.9 & 850 & 47.7 \\
\hline \multirow[t]{8}{*}{ After } & 1985 & 6 & 66.7 & 388 & 65.5 & 3 & 33.3 & 204 & 34.5 \\
\hline & 1986 & 3 & 42.9 & 301 & 47.0 & 4 & 57.1 & 339 & 53.0 \\
\hline & 1987 & 3 & 50.0 & 262 & 63.4 & 3 & 50.0 & 151 & 36.6 \\
\hline & 1988 & 7 & 77.8 & 583 & 62.3 & 2 & 22.2 & 353 & 37.7 \\
\hline & 1989 & 2 & 66.7 & 199 & 50.8 & 1 & 33.3 & 193 & 49.2 \\
\hline & 1990 & 4 & 44.4 & 823 & 51.0 & 5 & 55.6 & 791 & 49.0 \\
\hline & 1993 & 5 & 45.5 & 657 & 39.5 & 6 & 54.5 & 1008 & 60.5 \\
\hline & 1985-93 & 30 & 55.6 & 3213 & 51.4 & 24 & 44.4 & 3039 & 48.6 \\
\hline
\end{tabular}

Island, on the far eastern side of the delta (Figs. 2 and 3). Other new brood-rearing areas were established in 1990 in the Shaviovik River delta (Fig. 3, flock nos. 62 and 64) and along the Endicott Road (Fig. 3, flock nos. 60 and 74). These two new areas were used again in 1993, and brood- rearing habitats on Foggy Island, unoccupied by snow geese since 1987, were reoccupied in 1993.

During the 1985-93 post-development period, the mean distance moved by individually marked birds between brood-rearing areas in consecutive years was $8.0 \pm 7.5 \mathrm{~km}$. 
As during the pre-development period, however, $42.0 \%$ of the snow geese used areas within $3 \mathrm{~km}$ of areas used the previous year. After development, only $68.6 \%$ used areas $8 \mathrm{~km}$ or less from areas used the previous year, compared with $90.8 \%$ before development. After development, the bimodal peaks of distance moved from one year to the next were $3 \mathrm{~km}$ and $17 \mathrm{~km}$. The $17 \mathrm{~km}$ peak was heavily influenced by the pioneering movements in 1985 of flocks moving to brood-rearing areas in the Kadleroshilik River delta (Fig. 4).

The proportion of brood-rearing flocks captured east (vs. west) of the Endicott Road and Causeway (Table 2) was not significantly different before versus after the Endicott Development Project (Mann-Whitney $U=13.5$; $\mathrm{Z}$ corrected for ties $=-0.67 ; p=0.05 ; \mathrm{n}_{1}=5, \mathrm{n}_{2}=7$ ). Similarly, the proportions of total geese using broodrearing areas east of the road and causeway before vs. after petroleum development (Table 2) were virtually identical (Mann-Whitney $\mathrm{U}=15.0 ; \mathrm{Z}$ corrected for ties $=-0.41 ; p=$ $\left.0.68 ; \mathrm{n}_{1}=5, \mathrm{n}_{2}=7\right)$.

\section{DISCUSSION AND CONCLUSIONS}

\section{Fidelity to Brood-rearing Areas}

Few studies treat the fidelity of lesser snow geese to brood-rearing areas. Healey et al. (1980) reported on the traditional use of brood-rearing areas by lesser snow geese of the La Pérouse Bay colony, which consisted of 3000 3500 breeding pairs. Burgess and Ritchie (1987a, b,1988, 1989), Burgess and Stickney (1994), and Burgess et al. $(1990,1991)$ reported on the use of brood-rearing areas by Howe Island lesser snow geese. In general, the areas used by brood-rearing snow geese from both of these colonies were similar in extent $\left(>100 \mathrm{~km}^{2}\right)$. However, the specific brood-rearing locations used by Howe Island snow geese after flocks had stabilized were up to tenfold smaller than the broad areas used by family groups during post-hatching dispersal from Howe Island (Burgess and Ritchie, 1987a, b, 1988, 1989; Burgess and Stickney, 1994; Burgess et al., 1990, 1991). Burgess and colleagues found that snow geese reared broods in the same specific areas year after year; however, they did not band geese, so they were unable to determine the fidelity of individual birds to general or specific brood-rearing areas. On the other hand, Healey et al. (1980) found that snow geese are not randomly distributed in brood-rearing areas from one year to the next, but that many reared their broods in the same general areas for up to four years. Lindberg and Sedinger (1998) reported similar fidelity to brood-rearing areas by black brant (Branta bernicla nigricans) in the Yukon River delta, Alaska.

In this study, the consistency of use of the core area south of Howe Island and west of the Endicott Road by a large proportion of brood-rearing snow geese throughout the 14-year study, i.e., before and after petroleum development, indicated a strong preference for this area. Similarly, the large proportion (about $40 \%$ ) of snow geese that moved $3 \mathrm{~km}$ or less between brood-rearing areas in consecutive years before and after development indicates a marked fidelity to the same brood-rearing area from one year to the next.

It is possible that the $10-15$ pairs of tundra swans that occupied the Sagavanirktok River delta during and after 1985 prevented snow geese from using some potential brood-rearing habitat in the Sagavanirktok River delta. However, the lack of pre-1985 swan data weakens this argument. Tundra swans are very aggressive towards geese during the breeding season. Ely et al. (1987) reported tundra swans attacking and killing young white-fronted geese during the breeding season in the Yukon-Kuskokwim Delta, Alaska. Burgess and Stickney (1994) documented interspecific aggression by tundra swans against broodrearing snow geese and other geese in our study areas in the Sagavanirktok River delta during 1985-90, which coincides with the period of expansion to new brood-rearing areas by Howe Island snow geese. At least two pairs of tundra swans occupied Foggy Island during summer 1985 (LGL, unpubl. data), and this may have led to the eastward movement of brood-rearing flocks of snow geese from that area. No tundra swans were reported on Foggy Island during July 1993 (LGL, unpubl. data), which may explain why brood-rearing snow geese reoccupied the area in that year.

\section{Impacts of Petroleum Development}

Brood-rearing geese began to disperse farther from the nesting colony on Howe Island in 1985, the year following road and causeway construction. This dispersal, in part, may have been in response to increased industrial activities in the Sagavanirktok Delta during and after summer 1985. But the same proportion ( 40\%, Fig. 4) of geese reared broods within $3 \mathrm{~km}$ of their subsequent broodrearing location both before and after petroleum development. Furthermore, many snow geese continued to use brood-rearing areas close to the nesting colony, which are also close to oil field infrastructure (Figs. 2 and 3).

An alternative hypothesis is that the eastward expansion to new brood-rearing areas was a natural consequence of a tenfold increase in the Howe Island snow goose population over the course of the study (Table 1; Johnson, 1995). Although the Howe Island population is very small in relation to other populations in Canada and Russia, the areal extent of potential brood-rearing (salt marsh) habitats adjacent to the Howe Island nesting colony is also relatively small. However, no evidence has been found that the Howe Island snow goose population has overgrazed available brood-rearing habitats, as documented in some mid-continent snow goose populations (Kerbes et al., 1990; Ankney, 1996).

In conclusion, the hypothesis that the Endicott Road and Causeway has obstructed eastward movements of brood-rearing lesser snow geese must be rejected. 


\section{ACKNOWLEDGEMENTS}

Research on lesser snow geese in the Sagavanirktok River delta has been supported by BP Exploration (Alaska) Inc., ARCO Foundation and ARCO Alaska Inc., EXXON Company, LGL Alaska Research Associates Inc., the National Oceanic and Atmospheric Administration, Standard Alaska Production Company, and Sohio Alaska Petroleum Company. BP Exploration provided financial assistance for the preparation of this paper. I thank Dr. Christopher J. Herlugson of BP for his continued interest and support for the snow goose studies. Grateful thanks are due to the many biologists and friends who assisted with the field programs in the Sagavanirktok Delta, especially Chip Welling, who initiated the study in 1980. John Cole, Declan Troy, Craig Hohenberger, Rod Drewien, Ruth Shea, Bob Pollard, Chris Herlugson, Matt Cronin, Jim Hawkings, John Wright, Phil Martin, Bob Burgess, Bob Rodrigues, and Jo Young helped with the banding for many years. Benny Gallaway was instrumental in maintaining financial support for the study during several years. The U.S. Fish and Wildlife Service and the Alaska Department of Fish and Game have also supported our snow goose studies in various ways over the years. Comments by Gary Searing and Mike Demarchi of LGL Limited and three anonymous reviewers greatly improved an earlier version of this paper.

\section{REFERENCES}

ANKNEY, C.D. 1996. An embarrassment of riches: Too many geese. Journal of Wildlife Management 60:217-223.

BURGESS, R.M., and RITCHIE, R.J. 1987a. Snow goose monitoring program, 1985, Endicott Development Project. Report by Envirosphere Co., for U.S. Army Corps of Engineers, Anchorage, Alaska. Available from U.S. Army Corps of Engineers, P.O. Box 898, Anchorage, Alaska 99506-0898.

- 1987b. Snow goose monitoring program, 1986, Endicott Development Project. Report by Envirosphere Co., for U.S. Army Corps of Engineers, Anchorage, Alaska. Available from U.S. Army Corps of Engineers, P.O. Box 898, Anchorage, Alaska 99506-0898.

1988. Snow goose monitoring program, 1987, Endicott Development Project. Report by Envirosphere Co., for U.S. Army Corps of Engineers, Anchorage, Alaska. Available from U.S. Army Corps of Engineers, P.O. Box 898, Anchorage, Alaska 99506-0898.

1989. Snow goose monitoring program, 1988, Endicott

Development Project. Report by Science Applications International Corporation (SAIC), Inc., for U.S. Army Corps of Engineers, Anchorage, Alaska. Available from U.S. Army Corps of Engineers, P.O. Box 898, Anchorage, Alaska 99506-0898.

BURGESS, R.M., and STICKNEY, A.A. 1994. Interspecific aggression by tundra swans toward snow geese on the Sagavanirktok River delta, Alaska. Auk 111:204-207.

BURGESS, R.M., STICKNEY, A.A., ROSE, J.R., and RITCHIE, R.J. 1990. Snow goose monitoring program, 1989, Endicott Development Project. Report by Science Applications
International Corporation (SAIC), Inc., for U.S. Army Corps of Engineers, Anchorage, Alaska. Available from U.S. Army Corps of Engineers, P.O. Box 898, Anchorage, Alaska 995060898 .

1991. Snow goose monitoring program, 1990, Endicott Development Project. Report by Science Applications International Corporation (SAIC), Inc., for U.S. Army Corps of Engineers, Anchorage, Alaska. Available from U.S. Army Corps of Engineers, P.O. Box 898, Anchorage, Alaska 99506-0898.

COOKE, F., and ABRAHAM, K.F. 1980. Habitat and locality selection in lesser snow geese: The role of previous experience. Proceeding of the International Ornithological Congress 17:9981004.

ELY, C.R., BUDEAU, D.A., and SWAIN, U.G. 1987. Aggressive encounters between tundra swans and greater white-fronted geese during brood rearing. Condor 89:420-422.

GIROUX, J.-F., BEDARD, Y., and BEDARD, J. 1984. Habitat use by greater snow geese during the brood-rearing period. Arctic 37:155-160.

HEALEY, R.F., COOKE, F., and COLGAN, P.W. 1980. Demographic consequences of snow goose brood-rearing traditions. Journal of Wildlife Management 44:900-905.

HUGHES, R.J., REED, A., and GAUTHIER, G. 1994. Space and habitat use by greater snow goose broods on Bylot Island, Northwest Territories. Journal of Wildlife Management 58:536545.

JOHNSON, S.R. 1987. A preliminary nutritional and energetic evaluation of some plants eaten by lesser snow geese in broodrearing habitats, Sagavanirktok River delta area, Alaska. Report by LGL Alaska Research Associates, Inc., Anchorage, for Standard Alaska Production Co., Anchorage, Alaska. Available from BPExploration (Alaska) Inc., P.O. Box 196612, Anchorage, Alaska 99519-0612.

- 1994. The status of snow geese in the Sagavanirktok River delta area, Alaska, 1980-1993. Report by LGL Alaska Research Associates, Inc., for BP Exploration (Alaska) Inc., Anchorage, Alaska. Available from BP Exploration (Alaska) Inc., P.O. Box 196612, Anchorage, Alaska 99519-0612.

1995. Immigration in a small colony of lesser snow geese. Auk 112:731-736.

1996. Staging and wintering areas of lesser snow geese nesting on Howe Island, Alaska. Arctic 49:86-93.

JOHNSON, S.R., and HERTER, D.R. 1989. The birds of the Beaufort Sea. BP Exploration (Alaska) Inc., Anchorage, Alaska. Available from BP Exploration (Alaska) Inc., P.O. Box 196612, Anchorage, Alaska 99519-0612.

1990. Bird migration in the Arctic: A review. In: Gwinner, E., ed. Bird migration: Physiology and ecophysiology. Berlin and Heidelberg: Springer-Verlag. 22-43 .

JOHNSON, S.R., and TROY, D.M. 1987. Nesting of the Ross' Goose and blue-phase snow geese in the Sagavanirktok River delta, Alaska. Condor 89:665-667.

JOHNSON, S.R., SCHIECK, J.O., and SEARING, G.F. 1995. Neckband loss rates in lesser snow geese. Journal of Wildlife Management 59:747-752.

KERBES, R.H, KOTANEN, P.M., and JEFFERIES, R.L. 1990. Destruction of wetland habitats by lesser snow geese: A keystone 
species on the west coast of Hudson Bay. Journal of Applied Ecology 27:242-258.

LINDBERG, M.S., and SEDINGER, J.S. 1998. Ecological significance of brood-site fidelity in black brant: Spatial, annual, and age-related variation. Auk 115:436-446.

REED, A., and PLANTE, N. 1994. Decline in body mass, size, and condition of greater snow gese, 1975-94. Journal of Wildlife Management 61:413-419.
SEDINGER, J.S., and RAVELING, D.G. 1984. Dietary selectivity in relation to availability and quality of food for goslings of cackling geese. Auk 101:295-306.

TRUETT, J.C., MILLER, M.E., and KERTELL, K. 1997. Effects of Arctic Alaska oil development on brant and snow geese. Arctic 50:138-146.

APPENDIX 1. Capture-recapture histories of banded snow geese in different brood-rearing flocks in the Sagavanirktok River delta area, Alaska, $1980-93^{1}$. The numbers in the table are numbers of geese.

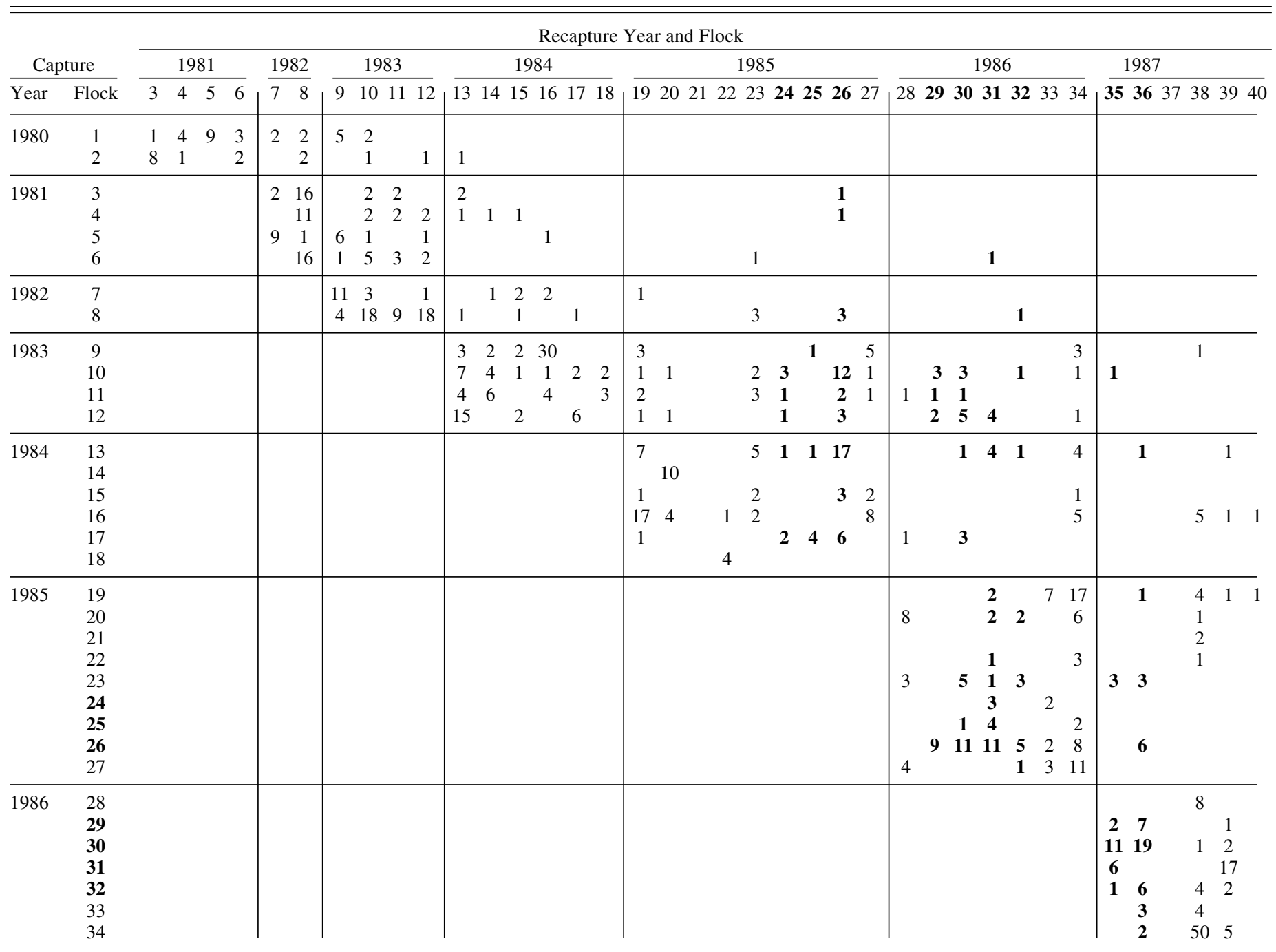

${ }^{1}$ Flock numbers and numbers of geese in bold are banded geese captured or recaptured in brood-rearing flocks east of the Endicott Road/ Causeway after commencement of construction during winter 1984-85 (see Figs. 2 and 3). 
APPENDIX 1. - cont. Capture-recapture histories of banded snow geese in different brood-rearing flocks in the Sagavanirktok River delta area, Alaska, $1980-1993^{1}$. The numbers in the table are numbers of geese.

\begin{tabular}{|c|c|c|c|c|c|c|c|c|c|c|c|c|c|c|c|c|c|c|c|c|c|}
\hline \multicolumn{22}{|c|}{ Recapture Year } \\
\hline \multicolumn{2}{|c|}{ Capture } & \multicolumn{4}{|c|}{1988} & \multicolumn{2}{|l|}{1989} & \multicolumn{6}{|c|}{1990} & 1991 & \multicolumn{7}{|c|}{1993} \\
\hline $\begin{array}{l}\text { Year } \\
1983\end{array}$ & $\begin{array}{c}\text { Flock } \\
9 \\
10 \\
11 \\
12\end{array}$ & 41 & & 4445 & 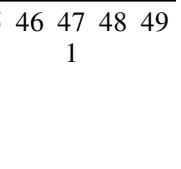 & 5051 & 52 & 535 & 5455 & & 5657 & 5859 & 596061 & $\overline{6263}$ & 646 & $6566 \quad 67$ & 6869 & 7071 & 7273 & 37 & \\
\hline 1984 & $\begin{array}{l}13 \\
14 \\
15 \\
16 \\
17 \\
18\end{array}$ & $\begin{array}{l}1 \\
1\end{array}$ & 1 & & & & & & & & & & & & & & & & & & \\
\hline 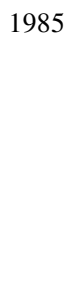 & $\begin{array}{l}19 \\
20 \\
21 \\
22 \\
23 \\
\mathbf{2 4} \\
\mathbf{2 5} \\
\mathbf{2 6} \\
27\end{array}$ & 2 & 1 & & 1 & 1 & & & & & & & & & & & & & & & \\
\hline 1986 & $\begin{array}{l}28 \\
\mathbf{2 9} \\
\mathbf{3 0} \\
\mathbf{3 1} \\
\mathbf{3 2} \\
33 \\
34 \\
\end{array}$ & $\begin{array}{l}1 \\
2 \\
1 \\
2 \\
1 \\
1\end{array}$ & $\begin{array}{l}2 \\
1 \\
2\end{array}$ & $\begin{array}{ll}3 & \\
1 & 3\end{array}$ & $\begin{array}{lll}5 & & \\
1 & 2 & 1\end{array}$ & $\begin{array}{l}1 \\
1 \\
1\end{array}$ & & & & & & & & & & & & & & & \\
\hline 1987 & $\begin{array}{l}\mathbf{3 5} \\
\mathbf{3 6} \\
37 \\
38 \\
39 \\
40\end{array}$ & $\begin{array}{c}18 \\
32 \\
\\
2 \\
17\end{array}$ & $\begin{array}{l}13 \\
6 \\
8\end{array}$ & $\begin{array}{ll}1 & \\
39 & 8 \\
1 & \end{array}$ & $\begin{array}{ll}254 \\
8\end{array}$ & $\begin{array}{ll}\mathbf{1} & \\
\mathbf{1} & \\
\mathbf{2} & 3 \\
1 & 1\end{array}$ & $\begin{array}{l}1 \\
1 \\
2\end{array}$ & $\begin{array}{l}1 \\
1\end{array}$ & $\begin{array}{l}1 \\
1\end{array}$ & & & & 1 & & & & & & & & \\
\hline 1988 & $\begin{array}{l}\mathbf{4 1} \\
\mathbf{4 2} \\
43 \\
44 \\
45 \\
46 \\
47 \\
48 \\
49\end{array}$ & & & & & $\begin{array}{cc}\mathbf{2 9} & \\
\mathbf{2} & \\
\mathbf{9} & 2 \\
\mathbf{1 1} & 16 \\
\mathbf{1} & 10 \\
\mathbf{1} & 25 \\
\mathbf{1} & 3\end{array}$ & $\begin{array}{l}2 \\
\\
\\
2 \\
1\end{array}$ & 47 & $\begin{array}{rr}7 & 4 \\
& 5 \\
& \end{array}$ & 4 & $\begin{array}{ll} & \\
6 & 1 \\
2 & \\
& \\
1 & \end{array}$ & $\begin{array}{ll}2 & \\
& \\
& 1 \\
1 & 7 \\
& 2 \\
& 8 \\
& \\
& 1 \\
& \\
& \\
& \end{array}$ & $\begin{array}{lll} & & \\
1 & 1 & 1 \\
7 & 2 & \\
2 & & \\
8 & 2 & \\
1 & & \end{array}$ & 2 & 13 & & & 1 & & & \\
\hline 1989 & $\begin{array}{l}\mathbf{5 0} \\
51 \\
52\end{array}$ & & & & & & & $\begin{array}{ll}4 & 6 \\
& 3 \\
& 1\end{array}$ & $\begin{array}{ll}\mathbf{6} & 7 \\
\mathbf{3} & \\
\mathbf{1} & 4\end{array}$ & 7 & $\begin{array}{ll}7 & \\
2 & \\
5 & 1\end{array}$ & $\begin{array}{ll} & 12 \\
8 \quad 38 \\
& 2\end{array}$ & $\begin{array}{cc}12 & 2 \\
38 & 9 \\
2 & \end{array}$ & 1 & 41 & 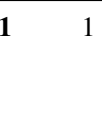 & 1 & & 1 & & \\
\hline 1990 & $\begin{array}{l}53 \\
\mathbf{5 4} \\
55 \\
56 \\
57 \\
58 \\
59 \\
60 \\
\mathbf{6 1}\end{array}$ & & & & & & & & & & & & & $\begin{array}{ll}2 & \\
2 & 2 \\
& 2 \\
2 & 1\end{array}$ & $\begin{array}{ll}2 & 2 \\
2 \\
3 \\
& \\
& \end{array}$ & $\begin{array}{lll}2 & & \\
2 & 2 & \\
3 & & 4 \\
& & 2 \\
& & \\
& & \\
& & \end{array}$ & $\begin{array}{ll}1 & \\
& 1 \\
1 & \\
3 & \\
1 & \\
& \\
1 & \\
& \\
1 & \end{array}$ & $\begin{array}{ll} & 1 \\
& \\
& \\
& \\
& 9\end{array}$ & $\begin{array}{l}3 \\
3 \\
8\end{array}$ & $\begin{array}{l}3 \\
3 \\
8\end{array}$ & $\begin{array}{l}3 \\
6\end{array}$ \\
\hline 1991 & $\begin{array}{l}62 \\
63\end{array}$ & & & & & & & & & & & & & & & 1 & $\begin{array}{l}2 \\
1\end{array}$ & & 2 & 2 & \\
\hline
\end{tabular}

\footnotetext{
${ }^{1}$ Flock numbers and numbers of geese in bold are banded geese captured or recaptured in brood-rearing flocks east of the Endicott Road/ Causeway after commencement of construction during winter 1984-85 (see Figs. 2 and 3).
} 